\title{
ER $\beta$ is a potent inhibitor of cell proliferation in the HCT8 human colon cancer cell line through regulation of cell cycle components
}

Valentina Martineti ${ }^{1,3,4}$, Lucia Picariello ${ }^{1,2}$, Isabella Tognarini ${ }^{1}$, Silvia Carbonell Sala ${ }^{1}$, Alessia Gozzini ${ }^{1}$, Chiara Azzari, ${ }^{2,3}$, Carmelo Mavilia ${ }^{1,3,4}$, Annalisa Tanini ${ }^{1,3,4}$, Alberto Falchetti ${ }^{1}$, Gianna Fiorelli ${ }^{1,2}$, Francesco Tonelli, ${ }^{1,2}$ and Maria Luisa Brandi ${ }^{1,3,4}$

\footnotetext{
${ }^{1}$ Department of Internal Medicine, School of Medicine, University of Florence, Viale Pieraccini 6, 50139 Florence, Italy

${ }^{2}$ Department of Clinical Physiopathology, School of Medicine, University of Florence, Viale Pieraccini 6, 50139 Florence, Italy

${ }^{3}$ Department of Pediatrics School of Medicine, University of Florence, Viale Pieraccini 6, 50139 Florence, Italy

${ }^{4}$ DEGENE Spin off, School of Medicine, University of Florence, Viale Pieraccini 6, 50139 Florence, Italy

(Requests for offprints should be addressed to M L Brandi; Email: m.brandi@dmi.unifi.it)
}

\begin{abstract}
Several strands of evidence indicate that oestrogens exert a protective role against the development of colon cancer through indirect and direct effects on colonic epithelium. Oestrogen receptor $\beta$ $(E R \beta)$, the predominant ER subtype in human colon, is significantly decreased in colonic tumours compared with normal mucosa suggesting a potential role in the regulation of colon tumour growth.

To investigate this hypothesis we engineered human colon cancer ER $\alpha$-negative HCT8 cells in order to obtain ER $\beta$ protein over-expression. Stably transfected cells were cloned and ER $\beta$ expression and functionality were monitored by RT-PCR, Western blotting and transactivation in an assay using oestrogen-responsive reporter constructs.

Over-expression of ER $\beta$ inhibited cell proliferation and increased cell adhesion in a ligandindependent manner. Its constitutive activation is possibly due to cross-talk with intracellular signalling pathways, as epidermal growth factor and IGF-I were able to induce ER $\beta$ transactivation.

A possible mechanism by which ER $\beta$ over-expression inhibits proliferation in HCT8 cells is by modulation of some key regulators of the cell cycle; there is a decrease in cyclin $\mathrm{E}$ and an increase in the cdk inhibitor p21CIP1. In fact, flow cytometry analysis provided evidence for blocking of the G1-S phase progression induced by ER $\beta$ over-expression. The magnitude of this effect was affected by the level of ER $\beta$ expression.

These results provide the first direct evidence that ER $\beta$ plays an important role in colon cancer as a regulator of cell proliferation through the control of key cell cycle modulators and arrest in G1-S phase transition. These findings are compatible with the hypothesis that the loss of ER $\beta$ expression could be one of the events involved in the development or progression of colon cancer.
\end{abstract}

Endocrine-Related Cancer (2005) 12 455-469

\section{Introduction}

Oestrogens seem to exert a protective role against development of colon cancer with a reduced relative risk (up to 0.56 ) in women currently receiving hormone replacement therapy (HRT) (Grodstein et al. 1998, Chlebowski et al. 2004) and a reduced mortality from this pathology (relative risk 0.71 in women who used
HRT and up to 0.55 in current users) (Calle et al. 1995).

Reasons for this protective effect include an oestrogen-induced decrease of both secondary bile acids and insulin-like growth factor I (IGF-I), a direct effect on the proliferation of colorectal epithelium, or a combination of these (Pasi \& Robert 2000). Several in vivo and in vitro studies support a direct effect of oestrogens 
on colonic epithelium. In fact, the expression of both oestrogen receptor (ER) subtypes, ER $\alpha$ and $\operatorname{ER} \beta$, has been demonstrated in colon cancer cell lines (Fiorelli et al. 1999, Arai et al. 2000, Nakayama et al. 2000, Campbell-Thompson et al. 2001) and in normal and cancerous colonic specimens (Foley et al. 2000, Campbell-Thompson et al. 2001, Weyant et al. 2001). In particular, ER $\beta$, identified as the predominant ER subtype expressed in human colon, has been observed to be significantly decreased in colonic tumours compared with normal mucosa, while ER $\alpha$ expression appeared to be substantially unchanged (Foley et al. 2000, Campbell-Thompson et al. 2001).

Overall, the physiological role of ERs in normal colon and their possible involvement in the aetiopathology of colon cancer is not well understood. This situation is further complicated by the complexity of species and isoform distribution of ERs, with consequent ligand tissue-specificity and by their low expression levels in colonic tissues with respect to classical oestrogen-dependent tissues.

The ER $\alpha: E R \beta$ ratio has been identified as a possible determinant of the susceptibility of a tissue to oestrogen-induced carcinogenesis, leading to the theory that binding of oestrogens to ER $\alpha$ induces a cancer promoting response, whereas binding to ER $\beta$ seems to exert a protective action (Weyant et al. 2001). A potential mechanism through which the two ERs exert such opposing action is by regulation of cyclin D1 gene transcription (Liu et al. 2002, Ström et al. 2004). Indeed, progress in the study of the molecular mechanism(s) of action of oestrogens has revealed why different cells can respond to the same hormone in a different manner. Reasons for this can reside in the different expression patterns of ER $\alpha$ and ER $\beta$ in vivo and in the need for them to interact with cellular transcription cofactors (coactivators and corepressors) which are not functionally equivalent and ubiquitously expressed in all cells (McDonnel \& Norris 2002).

In order better to understand and clarify the role of ER $\beta$ in proliferation and development of colon cancer cells, we selected a human colon adenocarcinoma cell line (HCT8), expressing only the ER $\beta$ subtype (Fiorelli et al. 1999), to be transfected with an appropriate plasmid for the over-expression of ER $\beta$. The present results demonstrate that over-expression of ER $\beta$ has an anti-proliferative effect, mostly due to ligand-independent activation of the receptor, and that this effect can be partially due to the modulation of some key regulators of the cell cycle with consequent cell cycle arrest in the G1-S phase transition.

\section{Materials and methods}

\section{Cell culture}

The human colon cancer HCT8 cell line (Tompkins et al. 1974, Picariello et al. 1997) was obtained from the American Type Cultures Collection (ATCC, Rockville, MD, USA). Cells were cultured in RPMI (Bio Whittaker, Walkersville, MD, USA) supplemented with $10 \%$ fetal calf serum (FCS; Biological Industries, Kibhutz Beit Haemek, Israel) until confluence, then detached with trypsin/ethylenediaminetetraacetic acid (EDTA) solution and plated at the desired density in the appropriate medium.

\section{Hormones and chemicals}

$17 \beta$-Oestradiol (17ßE2) and tamoxifen were purchased from Sigma (St Louis, MO, USA) and $\left[{ }^{3} \mathrm{H}\right] 17 \beta \mathrm{E} 2$ (specific activity $84.1 \mathrm{Ci} / \mathrm{mmol}$ ) was obtained from Dupont-New England Nuclear (Milan, Italy). ICI 164,384 was kindly provided by AstraZeneca (Macclesfield Cheshire, UK) and raloxifene was kindly provided by Lilly Research Laboratories (Indianapolis, IN, USA).

\section{Plasmids}

The control vector for $\beta$-galactosidase expression (pBLUE-TOPO) was purchased from Invitrogen (Life Technologies, Inc.) and pSV2neo was purchased from the ATCC. The pCXN2-hER $\beta$ mammalian expression vector for human ER $\beta$ protein was kindly provided by Dr S Inoue (Niwa et al. 1991) and pEREtkLUC reporter gene vector was kindly provided by Dr M G Parker (Cowley \& Parker 1999).

\section{Stable and transient transfection}

HCT8 cells were seeded in RPMI medium supplemented with $10 \%$ FCS, without antibiotics, and cultured at $37{ }^{\circ} \mathrm{C}$ in $5 \% \mathrm{CO}_{2}$ in air. After $24-48 \mathrm{~h}$, at $90-95 \%$ confluence, cells were transfected with $0.2 \mu \mathrm{g}$ plasmid (pCXN2-hER $\beta$ or pSV2neo) and $0.5 \mu 1$ Lipofectamine 2000 (Life Technologies, Inc) per $\mathrm{cm}^{2}$ of surface area according to the manufacturer's instructions. After $5 \mathrm{~h}$, medium was replaced and after an additional $48 \mathrm{~h}$, cells were split $1: 10$ in complete medium containing $800 \mu \mathrm{g}$ geneticin (G418, Gibco, Life Technologies, Inc.)/ml. Selection of stable transfected cells was carried out within 10-20 days of culture. Selected cells were finally cloned in 96-well plates by the dilution limit method. Stable transfected clones were then cultured and amplified in complete medium containing $200 \mu \mathrm{g}$ G418/ml. Transient co-transfection with the pEREtkLUC plasmid and with a control vector for 
Endocrine-Related Cancer (2005) 12 455-469

Table 1 Sequences and annealing temperatures for oligonucleotides used in RT-PCR experiments

\begin{tabular}{llll}
\hline Gene & Upper primer $\left(\mathbf{5}^{\prime}-\mathbf{3}^{\prime}\right)$ & & $\begin{array}{c}\text { Annealing } \\
\text { temperature } \\
\left.\mathbf{(}^{\circ} \mathbf{C}\right)\end{array}$ \\
\hline ER $\alpha$ & GGCCTTCTTCAAGAGAAGTATTC & TCTGGCGCTTGTGTTTCAACATT & 58 \\
ER $\beta$ & CTTACCTGTAAACAGAGAGACAC & TTGCGCCGGTTTTTATCGATTGT & 58 \\
EGF & GGGAAGATGACCACCACTAT & GTCTGCGTGGTGGTGCTTGT & 60 \\
EGFr & CTATGAGATGGAGGAAGACG & CAGAGGAGGAGTATGTGTGA & 56 \\
IGF-I & GGACCGGAGACGCTCTGCGGGG & GCGAGCTGACTTGGCAGGCTTG & 60 \\
IGF-Ir & CCAAAACTGAAGCCGAGAAG & ATCGATGCGGTACAATGTGA & 56 \\
\hline
\end{tabular}

$\beta$-galactosidase expression was performed following the above described protocol with minor modifications (and without G418 selection). Before transfection, cells were cultured in phenol red-free RPMI supplemented with $10 \%$ charcoal-stripped FCS for at least 2 days. After transfection, cells were starved in phenol redand FCS-free RPMI and then tested for luciferase activity after $24 \mathrm{~h}$ stimulation.

\section{RT-PCR}

Total RNA was obtained from $2 \times 10^{6}$ cells using the RNAwiz isolation reagent (Ambion, Austin, TX, USA) according to the manufacturer's instructions. $\mathrm{ER} \alpha, \mathrm{ER} \beta$, epidermal growth factor (EGF), IGF-I, the corresponding receptors (EGFr and IGF-Ir) and $\beta$-actin (control) mRNAs were retrotranscribed from HCT8 cells, from clones of ER $\beta$-transfected HCT8 cells and from control tissue total RNA using pairs of appropriate oligonucleotides (Table 1). RT-PCR was carried out in a $50 \mu \mathrm{l}$ reaction volume with the one-step system Titanium One-Step RT-PCR kit (Clontech, Palo Alto, CA, USA) according to the manufacturer's instructions. RT was performed for $1 \mathrm{~h}$ at $50^{\circ} \mathrm{C}$ and PCR for 35 cycles at specific annealing temperatures for each pair of primers as described in Table 1 . Transcripts were electrophoresed through a $2 \%$ agarose gel and visualized by ethidium bromide staining of the gel.

\section{Oestrogen binding studies}

Colon cancer cells were plated in 24-well plates in the appropriate growth media. After $24 \mathrm{~h}$, cells were plated in serum- and phenol red-free culture media and maintained overnight. Cells were then replaced in serum- and phenol red-free media supplemented with $10 \mathrm{mM}$ HEPES, pH 7.4, $0.1 \%$ ethanol, $0.1 \%$ BSA (binding buffer, BB) and incubated with increasing concentrations $(1-10 \mathrm{pM})$ of $\left[{ }^{3} \mathrm{H}\right] 17 \beta \mathrm{E} 2$ in the absence or presence of a 500 -fold molar excess of unlabelled
17ßE2. After $1 \mathrm{~h}$ incubation at $37^{\circ} \mathrm{C}$, cells were washed three times with $\mathrm{BB}$, lyzed with $1 \mathrm{M} \mathrm{NaOH}$, and neutralized with $1 \mathrm{M} \mathrm{HCl}$. The radioactivity present in the cellular lysate was measured in a $\beta$-counter. Each experiment was carried out in triplicate and binding data were analysed by Scatchard analysis.

\section{Cell morphology and doubling time}

General morphological and growth characteristics of transfected and untransfected HCT8 cells were studied by light microscopy and the evaluation of doubling time. For these studies cultured cells were used between the 29 th and 31 st passage. Aliquots of $5 \times 10^{2}$ cells were cultured in 60-mm dishes in RPMI supplemented with $10 \%$ FCS with or without $200 \mu \mathrm{g} \mathrm{G} 418 / \mathrm{ml}$ for seven days and then colonies were photographed. Doubling time was evaluated by culturing $10^{5}$ cells in 6-well plates in RPMI supplemented with $10 \%$ FCS with or without $200 \mu \mathrm{g} \mathrm{G} 418 / \mathrm{ml}$. Cells were counted every day, after trypsinization, for a seven-day period. Cell counts on triplicate cultures were performed using a Coulter counter.

\section{Luciferase assay}

After transient transfection with the pEREtkLUC reporter plasmid and pBLUE-TOPO, untransfected or ER $\beta$-transfected HCT8 cells were starved in phenol red- and FCS-free RPMI medium for $24 \mathrm{~h}$. Then, cells were stimulated in the same medium containing $0.1 \%$ ethanol with $10 \mathrm{nM} 17 \beta \mathrm{E} 2,1 \mu \mathrm{M}$ ICI 164,384 or both for $24 \mathrm{~h}$. When growth factors were tested, cells were stimulated in the same medium containing $0.1 \%$ BSA with EGF $(50 \mathrm{ng} / \mathrm{ml})$, IGF-I $(20 \mathrm{ng} / \mathrm{ml})$ or the combined agents, with or without $1 \mu \mathrm{M}$ ICI 164,384 . Whole cell extract was obtained with the luciferase assay system (Promega, Madison, WI, USA) and luciferase activity was determined using an LKB luminometer (LKB Instruments, Rockville, MD, USA). Luciferase activity was normalized to $\beta$-galactosidase 
activity, measured by a $\beta$-gal assay kit (Invitrogen, Life Technologies, Inc.), and to total protein concentration.

\section{Cell growth and viability}

Cells were plated on 6-well plates at a density of approximately $8 \times 10^{4}$ cells/well in complete medium. After $24 \mathrm{~h}$, cells were stimulated with different concentrations of 17ßE2 $(0.1-100 \mathrm{nM})$, raloxifene, tamoxifen or ICI $164,384(100 \mathrm{nM}$ or $1 \mu \mathrm{M})$, IGF-I ( 20 or $10 \mathrm{ng} / \mathrm{ml}$ ) or EGF ( 50 or $25 \mathrm{ng} / \mathrm{ml}$ ) in phenol red-free medium supplemented with $1 \%$ charcoalstripped FCS and $0.1 \%$ ethanol in the case of steroid stimuli. Treatment was repeated after 3 days and cells were detached with trypsin/EDTA after an additional 3 days. Cell number was evaluated by a Coulter counter in quadruplicate samples. On day 6 cells were also counted by the Trypan blue dye-exclusion test for evaluation of viability. Alternatively, cell proliferation was evaluated by use of an 3-(4, 5-dimethylthiazolyl2)-2, 5-diphenyltetrazolium bromide (MTT) assay performed with CellTiter 96 Aqueous One solution cell proliferation assay (Promega), a colorimetric method for the determination of the number of viable cells in proliferation or cytotoxicity assays. The assay was performed according to the manufacturer's instructions. Briefly, $5 \times 10^{3}$ cells/well were cultured in 96-well plates in complete medium with and without stimulants for one week. CellTiter solution $(20 \mu \mathrm{l})$ was added to each well in $100 \mu \mathrm{l}$ culture medium and the plate incubated for $1-4 \mathrm{~h}$ at $37^{\circ} \mathrm{C}$ in a humidified atmosphere, $5 \% \mathrm{CO}_{2}$ in air. The amount of soluble formazan produced by cellular reduction of MTT was determined, reading the absorbance at $490 \mathrm{~nm}$.

\section{Chromosome ladder}

Apoptosis was evaluated by lysing $5 \times 10^{6}$ cells cultured for one week in appropriate media, and visualizing the $180 \mathrm{bp}$ DNA fragmentation on $2 \%$ agarose gel using ApopLadder Ex kit (Takara Bio, Inc., Otsu, Shiga, Japan) according to the manufacturer's instructions.

\section{Western blotting}

In experiments to determine the effect of EGF and IGF-I stimulation on ERK phosphorylation, cells were pre-incubated with the MAP kinase inhibitor PD98059 (25 $\mu \mathrm{M}$; Sigma, Basel, Switzerland) for $30 \mathrm{~min}$ and then stimulated with EGF ( 25 or $50 \mathrm{ng} / \mathrm{ml}$ ) or IGF-I (10 or $20 \mathrm{ng} / \mathrm{ml}$ ) for $15 \mathrm{~min}$. Cytoplasmic and nuclear proteins were extracted from cells with an appropriate volume of M-PER mammalian protein extraction reagent (Pierce, Rockford, IL, USA), with the addition of proteases inhibitors (Complete, Mini from Roche, Basel, Switzerland) and phosphatase inhibitors (phosphatase inhibitor cocktail 1 and 2 from Sigma, USA), according to the manufacturer's instructions (protein extraction buffer). Proteins $(25 \mu \mathrm{g})$ were subjected to SDS-PAGE on a $10 \%$ (cyclin E, ER $\beta$ ), 12\% (cyclin D1, cdk2, cdk4, ERK1/2 and phospho-ERK1/2) or a $15 \%$ (p21CIP1 and p27KIP1) polyacrylamide gel and electrotransferred onto nitrocellulose membranes. After blotting, membranes were blocked with $1 \%$ Blocking reagent (BM Chemioluminescence Blotting System, Roche) when probed with monoclonal anti-ER $\beta$ N-19 (Santa Cruz Biotechnology, Inc., Santa Cruz, CA, USA) or with SuperBlock blocking buffer (Pierce) for anti-p27 (F-8), anti-p21 (F-5), anti-cyclin D1 (DCS-6), anti-cyclin E (M-20), anti-cdk2 (D-12), anti-cdk4 (H-303), anti- $\beta$-actin (C-2), anti-ERK1/2 and anti-phospho-ERK1(pThr202/ pTyr204)/ERK2(pThr185/pTyr187) antibodies. All primary antibodies were purchased from Santa Cruz Biotechnology Inc, except for anti ERK1/2 antibodies which were purchased from Sigma (Switzerland). Incubation with primary antibodies was performed for $1 \mathrm{~h}$ under gentle agitation at room temperature in the appropriate blocking buffer with different Tween-20 concentrations depending on the antibody. Application of the horseradish peroxidase-conjugated secondary antibody $(1: 1000)$, anti-mouse IgG, anti-rabbit IgG or anti-goat IgG (Sigma, Switzerland), was carried out for $45 \mathrm{~min}$ at room temperature and subsequent signal detection, using enzyme-linked chemiluminescence (Supersignal chemiluminescent substrate' from Pierce), was performed according to the manufacturer's instructions. Membranes were then stripped in Restore Western Blot stripping buffer (Pierce) for $10 \mathrm{~min}$ at $37^{\circ} \mathrm{C}$ and re-probed with monoclonal anti $\beta$-actin for quantitative analysis. This was performed by acquiring images from X-ray films with a Kodak (Rochester, NY, USA) imaging system to obtain band intensities. In Western blot with anti-phospho-ERK1 (pThr202/pTyr204)/ERK2(pThr185/pTyr187) antibody, after stripping, the membrane was re-incubated with secondary antibody and the presence of residual signal was detected by chemiluminescence as previously described. Then the membrane was re-probed with anti-ERK1/2 antibody as described.

\section{Immunoprecipitation and kinase assay}

For immunoprecipitation and $\mathrm{H} 1$ kinase assays, $400 \mu \mathrm{g}$ cell extracts were used per immunoprecipitation with antibody to cyclin E $(2 \mu \mathrm{g})$. The antibody binding reaction was carried out in protein extraction at 
$4{ }^{\circ} \mathrm{C}$ overnight. The protein/antibody mixture was incubated with Protein A/G PLUS-Agarose beads (Santa Cruz Biotechnology, Inc.) for $1 \mathrm{~h}$ and then washed twice with protein extraction buffer and twice

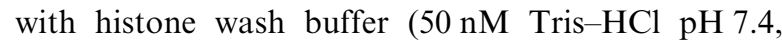
$30 \mu \mathrm{M}$ ATP, $10 \mathrm{nM} \mathrm{MgCl}_{2}, 1 \mathrm{nM}$ dithiothreitol). Immunoprecipitates were then analysed by either Western blot analysis or H1 kinase assay. For Western blot analysis, Protein A/G PLUS-Agarose beads from the immunoprecipitation were boiled in Laemmli sample buffer (Bio-Rad Laboratories) and proteins were separated on a $12 \%$ SDS-PAGE gel. Western blotting was performed with monoclonal anti-CDK2 as previously described. For the kinase assay, immunoprecipitates were incubated with histone assay solution $\left(200 \mu \mathrm{g} / \mathrm{ml}\right.$ histone $\mathrm{H} 1, \quad 100 \mu \mathrm{Ci} / \mathrm{ml} \quad\left[{ }^{32} \mathrm{P}\right] \gamma \mathrm{ATP}$ in histone wash buffer) in a final volume of $50 \mu \mathrm{l}$ at $30{ }^{\circ} \mathrm{C}$ for $20 \mathrm{~min}$. $\mathrm{H} 1$ kinase reactions were analysed on a $12 \%$ SDS-PAGE gel. The gel was then dried and exposed to X-ray film.

\section{Flow cytometric analysis}

For flow cytometric analysis, HCT8, HCT8pSV2neo, and all transfectant clones were harvested in salineEDTA, fixed in cold $70 \%$ ethanol, and stored at $-20{ }^{\circ} \mathrm{C}$ for $30 \mathrm{~min}$. Fixed cells were subsequently stained with propidium iodide (Sigma) for $30 \mathrm{~min}$ in the dark and analysed in a FACScan flow cytometer (Becton Dickinson Labware, Lincoln Park, NJ, USA) with an excitation wavelength of $488 \mathrm{~nm}$. The resulting histograms were analysed by MODFIT software (Becton Dickinson Labware) for cell distribution in the cell cycle phase. The proliferative fraction in the culture was determined as cells in the $\mathrm{S}$ and $\mathrm{G} 2 / \mathrm{M}$ phases of the cell cycle based on DNA content.

\section{Statistics}

Data were expressed as means \pm s.D. Statistical differences among mean values were analysed using Scheffe's test (Statistica 5.1; Statsoft Inc, Tulsa, OK, USA).

\section{Results}

\section{Human colon cancer cell model stably expressing ER $\beta$}

Among twelve clones resistant to G418, the one that showed maximal expression of ER $\beta$, as verified by RT-PCR, quantitative Western blotting and binding experiments (about 35000 binding sites compared with 3500 detected in wild type HCT8), was named HCT8- $\beta 8$ and used for subsequent experiments (Fig. 1A-C). However, experiments regarding key features of the cellular model such as growth curves and morphological analysis have been performed even on clones expressing intermediate levels of ER $\beta$ protein to confirm that the HCT8- $\beta 8$ phenotype was really due to the over-expression of the receptor (data not shown).

\section{Functionality of the over-expressed ER $\beta$ protein}

As shown in Fig. 1D, 17ßE2 induced a 10-fold increase in luciferase expression compared with that of control cells. On the other hand, ICI 164,384 alone did not affect transactivation, but almost abolished the effect of $17 \beta \mathrm{E} 2$. As shown in the inset panel of the figure, endogenous ER $\beta$ expression was not detectable by this method.

\section{Effect of liganded and unliganded over- expressed ER $\beta$ on cell proliferation}

In basal conditions, proliferation of HCT8- $\beta 8$ cells was significantly ( $\sim$ fivefold) lower than for HCT8pSV2neo cells. Exposure to 17ßE2 $(0.1-100 \mathrm{nM})$ produced a biphasic, although not significant, stimulatory effect on HCT8pSV2neo cell growth, while $100 \mathrm{nM} 17 \beta \mathrm{E} 2$ significantly inhibited HCT8- $\beta 8$ cell proliferation (Fig. 2A). 17ßE2 at doses of $0.1-100 \mathrm{nM}$ did not influence cell viability of HCT8- $\beta 8$ and HCT8pSV2neo cells ( $\sim 95 \%$ vs $\sim 90 \%$ viability respectively). We tested the effect of two doses $(100 \mathrm{nM}$ and $1 \mu \mathrm{M})$ of the antagonists ICI 164,384, tamoxifen and raloxifene on HCT8 cell growth in the presence or absence of overexpressed ER $\beta$. As reported in Fig. 2C only the $1 \mu \mathrm{M}$ concentration of all chemicals was shown to be effective on HCT8pSV2neo and on HCT8- $\beta 8$ cell proliferation by significantly inhibiting cell growth, but the percentage reduction induced by all three chemicals was similar in HCT8pSV2neo and HCT8- $\beta 8$ while the different absolute cell numbers reached both in control and stimulated cells was lower in transfected cells.

\section{Effect of ER $\beta$ over-expression on cell morphology}

Morphological and growth characteristics of the HCT8- $\beta 8$ cell line compared with HCT8pSV2neo cells were evaluated by contrast phase microscopy and by determination of lag and doubling times. HCT8pSV2neo cells grew in multilayered large colonies, assuming a spindle-shaped morphology while HCT8- $\beta 8$ cells showed a polygonal shape growing in small colonies and never in multilayers (Fig. 3A). These observations were confirmed by measuring lag and doubling times of the two cell populations. The lag 

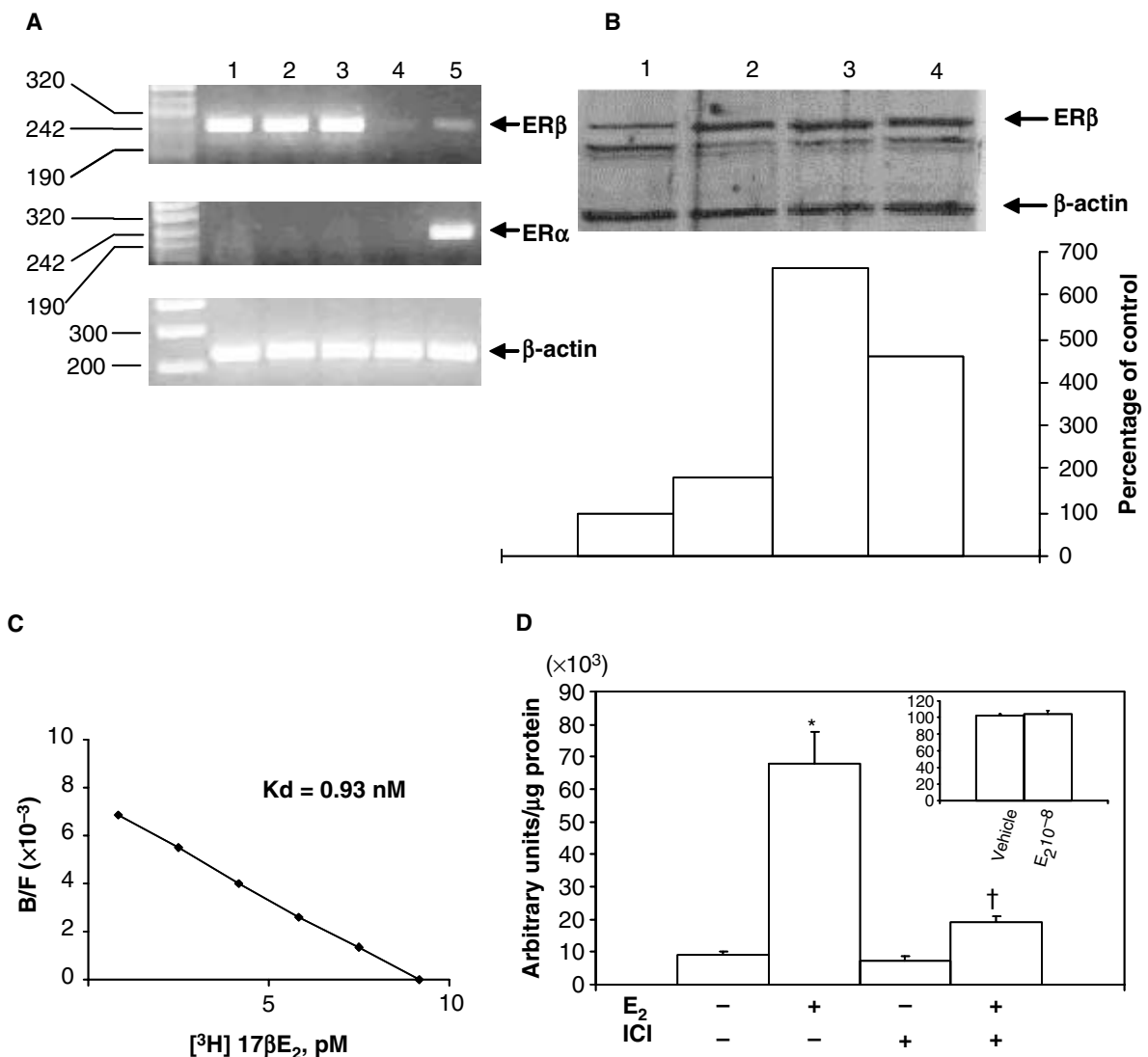

Figure 1 Analysis of ER $\beta$ expression levels and of receptor functionality in transfected cells. (A) RT-PCR of ER $\alpha$ and ER $\beta$ on HCT8- $\beta 6$ (lane 1), - $\beta 8$ (lane 2), - $\beta 11$ (lane 3) clones, on HCT8 cells (lane 4) and on ovarian tissue (lane 5). (B) Quantitative Western blot of ER $\beta$ protein expression on HCT8 cells (lane 1), HCT8- $\beta 6$ (lane 2), - $\beta 8$ (lane 3) and - $\beta 11$ (lane 4 ) clones. (C) Binding experiment on HCT8- $\beta 8$ clone. (D) Transactivation of ER $\beta$ protein by $17 \beta E 2\left(E_{2}\right)$ in HCT8- $\beta 8$ and in HCT8 cells (inset) and the effects of $\mathrm{ICl} 164,384(\mathrm{ICl})$. Values are expressed in arbitrary units and normalized against $\beta$-galactosidase expression and protein content and are the mean value \pm S.D. of three separate experiments. ${ }^{*} P<0.05$ vs untreated cells, $\dagger P<0.05$ vs $17 \beta \mathrm{E} 2$-treated cells.

times of HCT8- $\beta 8$ cells and of HCT8pSV2neo cells were respectively $58 \mathrm{~h}$ and $38 \mathrm{~h}$, and the doubling times were $59 \mathrm{~h}$ and $31 \mathrm{~h}$ respectively (Fig. 3B). Measurement of the same parameters in the HCT8- $\beta 6$ cell line, a clone showing a twofold increase in ER $\beta$ overexpression (Fig. 1B), revealed intermediate values (lag time: $48 \mathrm{~h}$ and doubling time: $39 \mathrm{~h}$ ).

\section{Effect of EGF and IGF-I on ER $\beta$ transactivation and on cell proliferation}

In order to verify potential actions of growth factors on over-expressed ER $\beta$ protein, a luciferase transactivation assay was performed on HCT8- $\beta 8$ cells transiently co-transfected with the pEREtkLUC plasmid or with the internal control plasmid pBLUE-TOPO. After $24 \mathrm{~h}$ in phenol red- and FCS-free RPMI,
HCT8- $\beta 8$ cells were treated with vehicle (control), $10 \mathrm{nM}$ 17ßE2, $1 \mu \mathrm{M}$ ICI 164,384, $50 \mathrm{ng} \mathrm{EGF/ml,} 20 \mathrm{ng}$ IGF-I $/ \mathrm{ml}$, and with the combined agents for $24 \mathrm{~h}$. EGF and IGF-I induced respectively a 2.5 -fold and a 4-fold increase in luciferase expression compared with that of controls (Fig. 4A). The two combined growth factors induced an even higher expression of luciferase (6-fold) and this effect was only partially reversed by the addition of ICI 164,384 (Fig. 4A), which in turn almost completely abolished the effect of $17 \beta \mathrm{E} 2$ (Fig. 1D).

As EGF and IGF-I proved to be potent activators of ER $\beta$ in this cell model, we investigated if the antiproliferative effect of the receptor could be associated with its stimulation by these growth factors by analysing their effects on untransfected and HCT8- $\beta 8$ cell lines. In HCT8pSV2neo neither IGF-I (10 and 

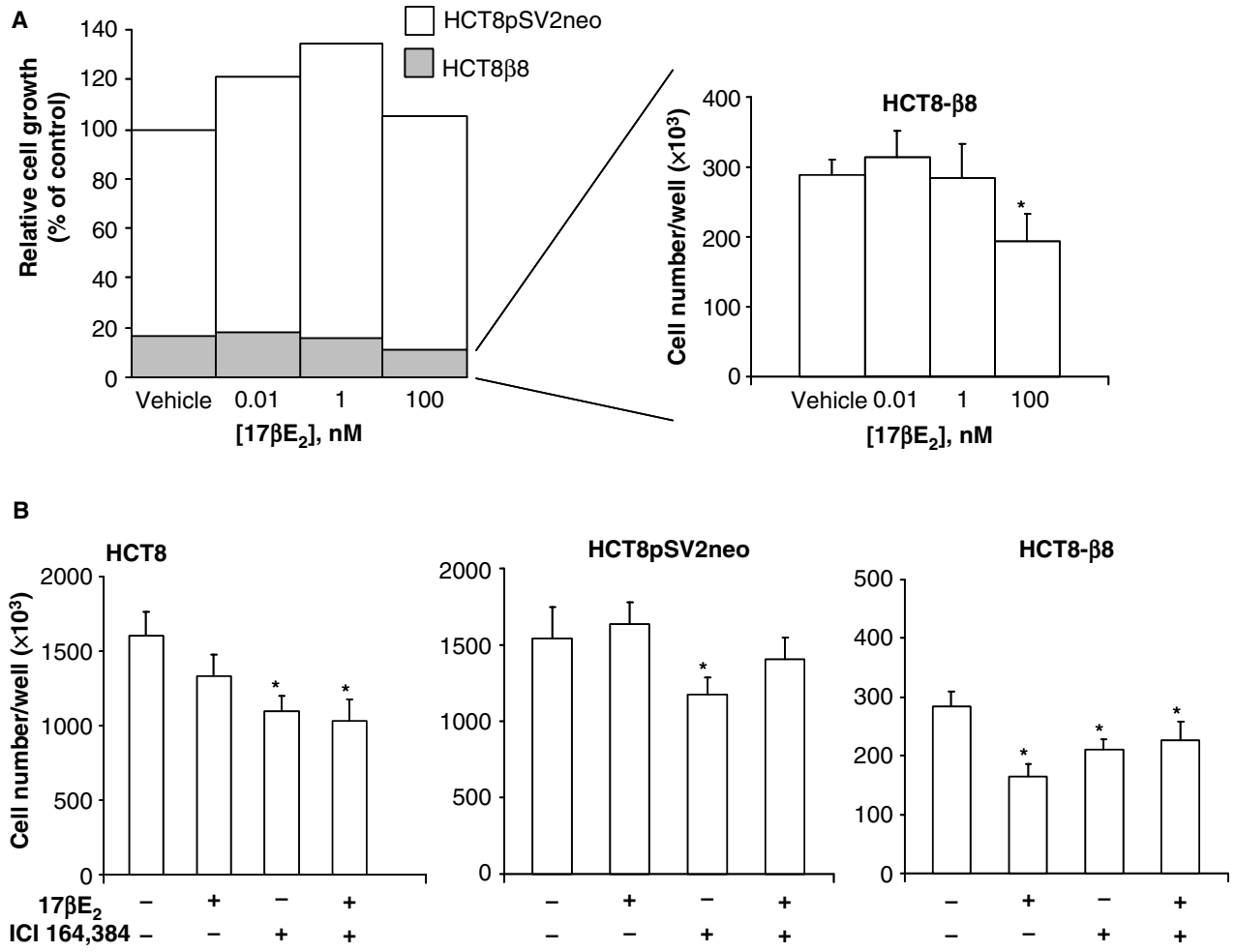

C
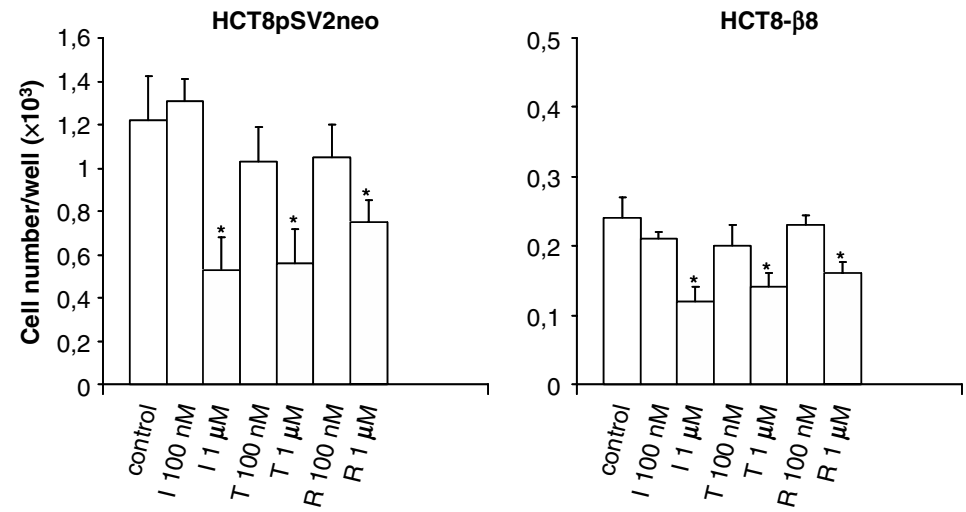

Figure 2 Effect of $17 \beta E 2$ and of different ER antagonists on colon cancer cell proliferation. (A) Effect of $17 \beta E 2$ on growth of HCT8pSV2neo and HCT8- $\beta 8$ cells. Cells were treated with vehicle or $17 \beta E 2$ at different concentrations $(0.01,1$ and $100 \mathrm{nM})$ in phenol red-free medium supplemented with 1\% charcoal-stripped FCS. Treatments were repeated after 3 days in fresh medium. After 6 days, cell number was evaluated using a Coulter counter. Results are expressed as the mean value of four separate experiments carried out in triplicate and are expressed as relative cell growth in the left panel (percentage of the control, untreated HCT8pSV2neo cells) and as cell number/well in the right panel. * $P<0.05$ vs untreated cells. (B) Effects of $17 \beta E 2$ on HCT8, HCT8pSV2neo and HCT8- $\beta 8$ cell growth in the absence or presence of ICl 164,384 (ICI). Cells were treated with vehicle, $17 \beta \mathrm{E} 2(100 \mathrm{nM}), \mathrm{ICl}(1 \mu \mathrm{M})$ or with the combined treatments in phenol red free-medium supplemented with $1 \%$ charcoal-stripped FCS. After 3 days, medium was replaced with fresh medium containing the appropriate stimulants and, on day 6 , cell number was evaluated using a Coulter counter. Results are expressed as the mean value \pm S.D. of four separate experiments carried out in triplicate. ${ }^{*} P<0.05$ vs untreated cells. (C) Cells were treated with vehicle, ICI 164,384 (I), tamoxifen $(\mathrm{T})$ or raloxifene $(\mathrm{R})$ at two different concentrations $(100 \mathrm{nM}$ and $1 \mu \mathrm{M})$ in phenol red-free medium supplemented with $1 \%$ charcoal-stripped FCS. Treatments were repeated after 3 days in fresh medium. After 6 days cell number was evaluated by the MTT test. Results are expressed as the mean value \pm S.D. of four separate experiments carried out in triplicate. ${ }^{*} P<0.05$ vs untreated cells. 
A

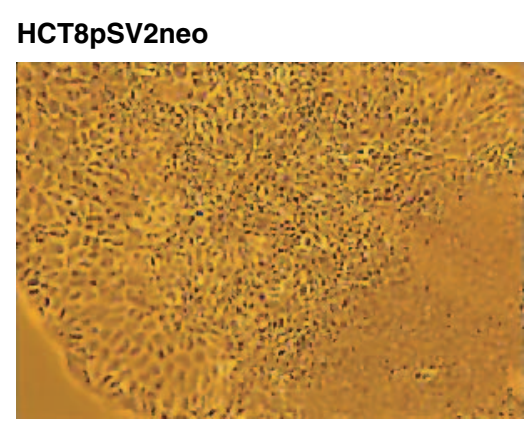

HCT8- $\beta 8$

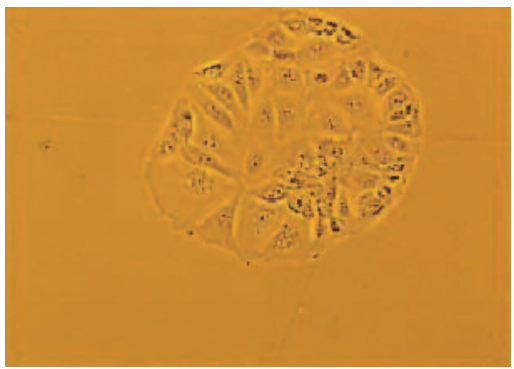

B
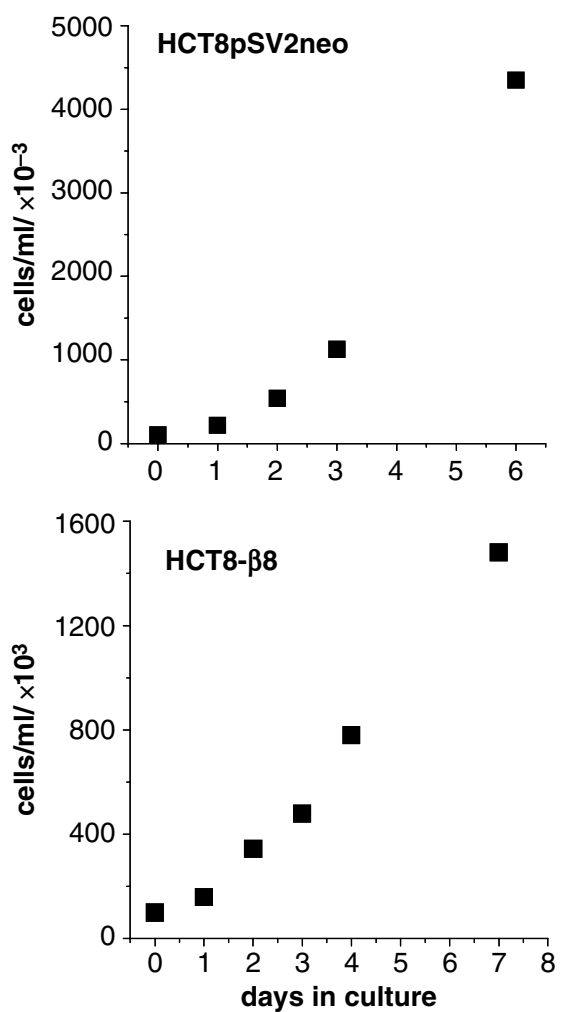

Figure 3 Morphological and growth characteristics of HCT8- $\beta 8$ cells. (A) Phase-contrast light microscopy of HCT8pSV2neo cells $(\times 100)$ and of HCT8- $\beta 8$ cells $(\times 150)$ in monolayer cultures. While HCT8pSV2neo cells rapidly formed large colonies, assuming a narrowed and filamentous shape, HCT8- $\beta 8$ cells formed small and sparse colonies where cells never acquired a narrowed shape and never grew in multilayers. (B) Growth curves of HCT8pSV2neo and HCT8- $\beta 8$ cells.

$20 \mathrm{ng} / \mathrm{ml}$ ) nor EGF (25 and $50 \mathrm{ng} / \mathrm{ml}$ ) had significant effects on cell proliferation (Fig. 4B).

We analysed EGF, EGFr, IGF-I and IGF-Ir mRNA expression in HCT8pSV2neo and HCT8- $\beta 8$ cell lines by RT-PCR and showed that both cell lines express the corresponding mRNA (Fig. 5A). Moreover, EGF and IGF-I stimulate their classical signal transduction cascade through activation of MAP kinases as demonstrated for HCT8- $\beta 8$ cells in Fig. 5B where a significant increase in phospho-ERK1 and phosphoERK2 (upper panel) proteins is observed in respect to their total content (lower panel) after cell stimulation with different doses of EGF and IGF-I.

\section{Effect of ER $\beta$ over-expression on apoptosis}

We performed chromosome ladder analysis on HCT8pSV2neo cells and on three clones expressing different levels of transfected ER $\beta$ protein in order to investigate the role of apoptosis in mediating the antiproliferative effect of the over-expression of the receptor in this cell model. No evidence of $180 \mathrm{bp}$ DNA fragmentation was present in untransfected cells or in three ER $\beta$-over-expressing clones (data not shown).

\section{Unliganded ER $\beta$ modulates some cell cycle components causing HCT8 cells arrest in G1-S}

Western blot analysis of cdk4, cyclin D1, cdk2, cyclin $\mathrm{E}$ and of their direct inhibitors p21CIP1 and p27KIP1 was performed on cell extracts of HCT8pSV2neo and of HCT $8-\beta 8$ and $-\beta 6$ clones showing seven- and twofold higher ER $\beta$ expression levels respectively compared with HCT8pSV2neo cells (Fig. 1B). Expression of cdk4 was up-regulated in both HCT8- $\beta 6$ and HCT8- $\beta 8$ clones (Fig. 6A). Conversely, cyclin D1, the major partner in the active cdk4 complex, was unaffected by ER $\beta$ over-expression (Fig. 6B).

Regarding the cdk2 complex, the other main cell cycle promoter complex, ER $\beta$ over-expression did not 
A

$\left(\times 10^{3}\right)$

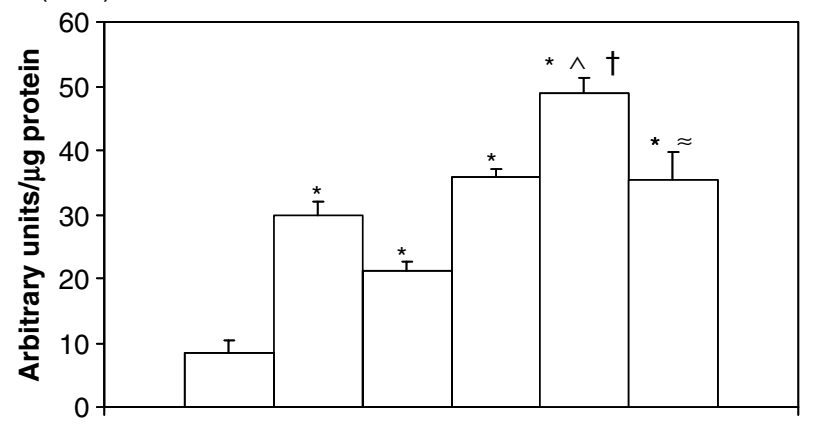

$\begin{array}{lllllll}\mathrm{E}_{2} & - & + & - & - & - & - \\ \mathrm{ICI} 164,384 & - & - & - & - & - & + \\ \mathrm{EGF} & - & - & + & - & + & + \\ \text { IGF-I } & - & - & - & + & + & +\end{array}$
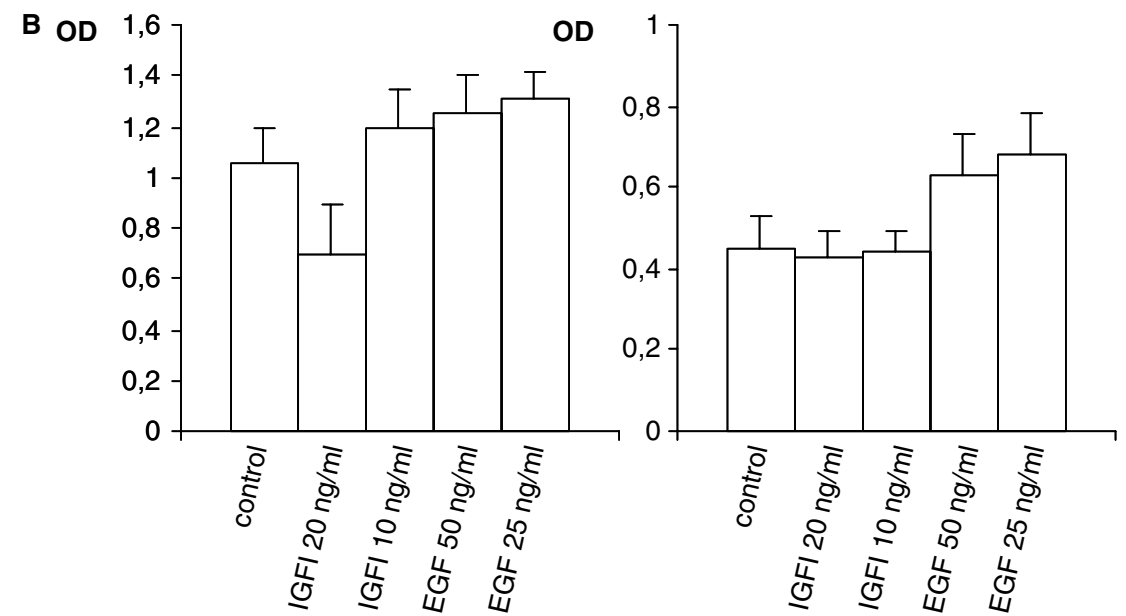

Figure 4 Effects of growth factors on ER $\beta$ over-expressing HCT8- $\beta 8$ clone. (A) Transactivation of ER $\beta$ protein by growth factors in HCT8- $\beta 8$ cells. Cells, transiently transfected with pEREtkLUC, were treated with vehicle, $17 \beta E 2\left(E_{2} ; 10 \mathrm{nM}\right), I C l 164,384$ $(1 \mu \mathrm{M})$, EGF $(50 \mathrm{ng} / \mathrm{ml})$, IGF-I $(20 \mathrm{ng} / \mathrm{ml})$, or the combined agents for $24 \mathrm{~h}$ in phenol red- and FCS-free medium and were then assayed for luciferase activity. Values, expressed as arbitrary units and normalized against $\beta$-galactosidase expression and protein content, are represented as the mean value \pm S.D. of three separate experiments. ${ }^{*} P<0.05$ vs untreated cells; $\wedge P<0.05$ vs $17 \beta E 2$-treated cells; $\dagger P<0.05$ vs EGF- or IGF-I-treated cells; and $\approx P<0.05$ vs EGF + IGF-I-treated cells. (B) Growth curve of HCT8 cells (left panel) and the HCT8- $\beta 8$ clone (right panel) in the presence of EGF or IGF-I at different concentrations. Cells were exposed to EGF (50 or $25 \mathrm{ng} / \mathrm{ml}$ ) or IGF-I (20 or $10 \mathrm{ng} / \mathrm{ml}$ ) in phenol red free-medium supplemented with $1 \%$ charcoalstripped FCS. After 3 days the medium was replaced with fresh medium containing the appropriate stimulants and, on day 6 , cell number was evaluated by the MTT test. Results are expressed as the mean value \pm S.D. of four separate experiments carried out in triplicate.

affect expression level of the kinase protein (Fig. 6C) but drastically (6 times) reduced cyclin E protein (Fig. $6 \mathrm{D})$ in the HCT8- $\beta 8$ but not in the HCT8- $\beta 6$ clone. Finally, ER $\beta$ over-expression did not affect p27KIP1 expression level (Fig. 6E) but doubled that of p21CIP1 (Fig. 6F), which is a common inhibitor of both active cdk4 and cdk2 complexes.

Activity of the cdk2/cyclin E complexes immunoprecipitated from cells was markedly decreased in the HCT8- $\beta$ clone relative to those from the
HCT8pSV2neo, causing a decrease of cells in the proliferative fraction $\mathrm{S}+\mathrm{G} 2 / \mathrm{M}$. Immunoprecipitates from HCT8- $\beta 6$ cells showed an intermediate level of activity corresponding to an intermediate fraction of non-resting cells (Fig. 7).

\section{Discussion}

The presence of functional oestrogen receptors has been described in normal and cancerous colon tissues 


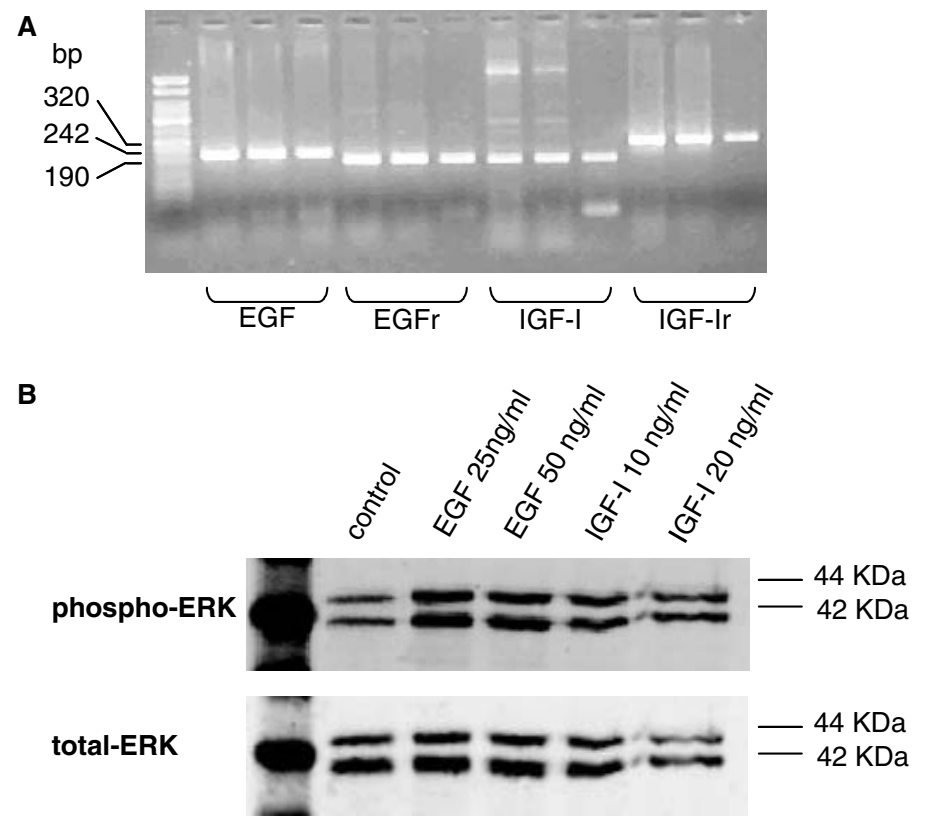

Figure 5 Presence of an EGF and IGF-I stimulating autocrine loop in HCT8 cells. (A) Expression of endogenous EGF, EGFr, IGF-I and IGF-Ir mRNAs in HCT8 (left lane), HCT8- $\beta 8$ (central lane) and control tissues (right lane) analysed through RT-PCR. Control tissues are normal colonic mucosa for EGF, fetal liver for EGFr and IGF-I, and lymphocytes for IGF-Ir. (B) EGF and IGF-I induction of ERK1/2 phosphorylation in HCT8- $\beta 8$ cells. Cells were pre-incubated with the MAP kinase inhibitor PD-98059 for $30 \mathrm{~min}$ and then stimulated with EGF ( 25 or $50 \mathrm{ng} / \mathrm{ml}$ ) or IGF-I (10 or $20 \mathrm{ng} / \mathrm{ml}$ ) for $15 \mathrm{~min}$. Phosphorylated ERK1 and ERK2 (upper panel) were analysed by Western blotting versus total amount of ERK1/2 (lower panel).

as well as in various colon cancer cell lines supporting a physiological role of oestrogens in the biology of colonic mucosa. Expression of the sole ER $\beta$ subtype has been demonstrated in HCT8, LoVo (Fiorelli et al. 1999), DLD-1 (Fiorelli et al. 1999, Nakayama et al. 2000), HCT116 (Fiorelli et al. 1999, Arai et al. 2000), Colo320, SW480 (Arai et al. 2000), HT29 (Arai et al. 2000, Campbell-Thompson et al. 2001), SW1116, SW48, and T84 (Campbell-Thompson et al. 2001) cell lines. Moreover, studies from different laboratories on paired samples of normal and neoplastic mucosa revealed the presence of higher levels of ER $\beta$ compared with ER $\alpha$ in normal mucosa and a selective loss of ER $\beta$ protein in malignant colon cancer (Foley et al. 2000, Campbell-Thompson et al. 2001). These findings, together with a lower colon cancer incidence and mortality in females (Levi et al. 1991, deCosse et al. 1993, Ries et al. 2000) and a reduced cancer risk in postmenopausal women taking HRT (Calle et al. 1995, Kampmann et al. 1997, Grodstein et al. 1998, 1999, Nanda et al. 1999, Chlebowski et al. 2004), suggested a role for oestrogens in colon tumorigenesis through an effect on ER $\beta$.

Moreover, in vitro studies on the effects of oestrogens on proliferation of human colon cancer cell lines produced conflicting results (Fiorelli et al. 1999, Arai et al. 2000). These discrepancies could be explained by the low level of expression of the two ERs and/or by their different transcriptional activities in different cell models. Over-expression of ER $\beta$ in colon cancer cells expressing solely ER $\beta$ was, therefore, selected as a possible strategy to elucidate the action of ER $\beta$ on in vitro growth of colon cancer cells. In agreement with previous findings in other cellular models (Lazennec et al. 2001, Ström et al. 2004, Paruthiyil et al. 2004), transfected ER $\beta$ protein appears to be fully functional with stimulation of the estrogen responsive element (ERE)-containing reporter gene by $17 \beta E 2$ and inhibition by the pure antioestrogen ICI 164,384.

Over-expression of ER $\beta$ receptor was able to induce a fivefold reduction in HCT8- $\beta 8$ cell proliferation. Moreover, HCT8- $\beta 8$ cells exhibited morphological features different from the parent cell line, with a flattened polygonal shape, lack of growth in multilayers and resistance to trypsin-induced detachment. These findings clearly showed that ER $\beta$ plays an important role in colon cancer cell proliferation and morphological features and that its action is almost completely disengaged from its binding to oestrogens. In agreement with this interpretation, cells with an 
A

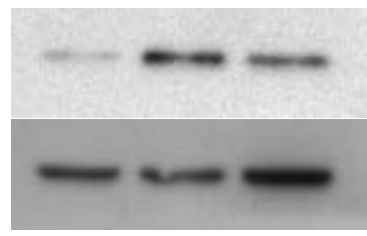

B

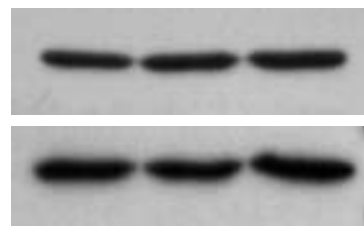

C

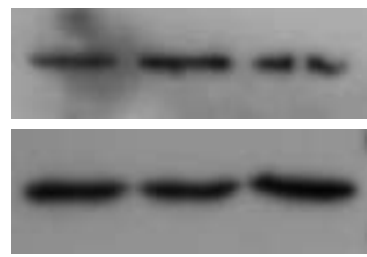

D

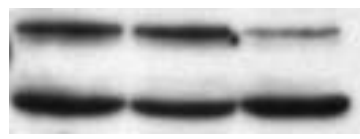

E

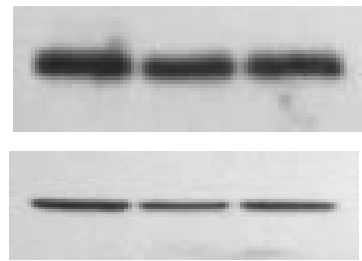

$\mathbf{F}$

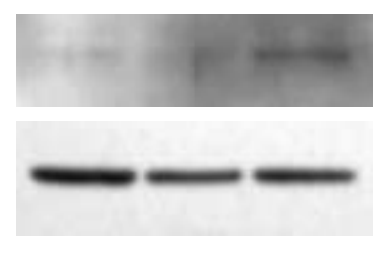<smiles>O=C1CCCCC1=O</smiles>

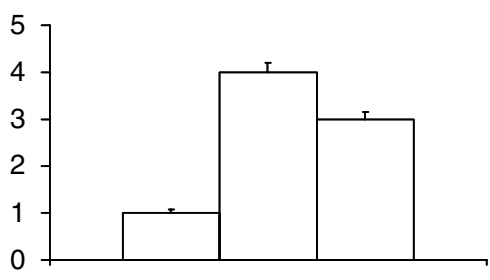

0
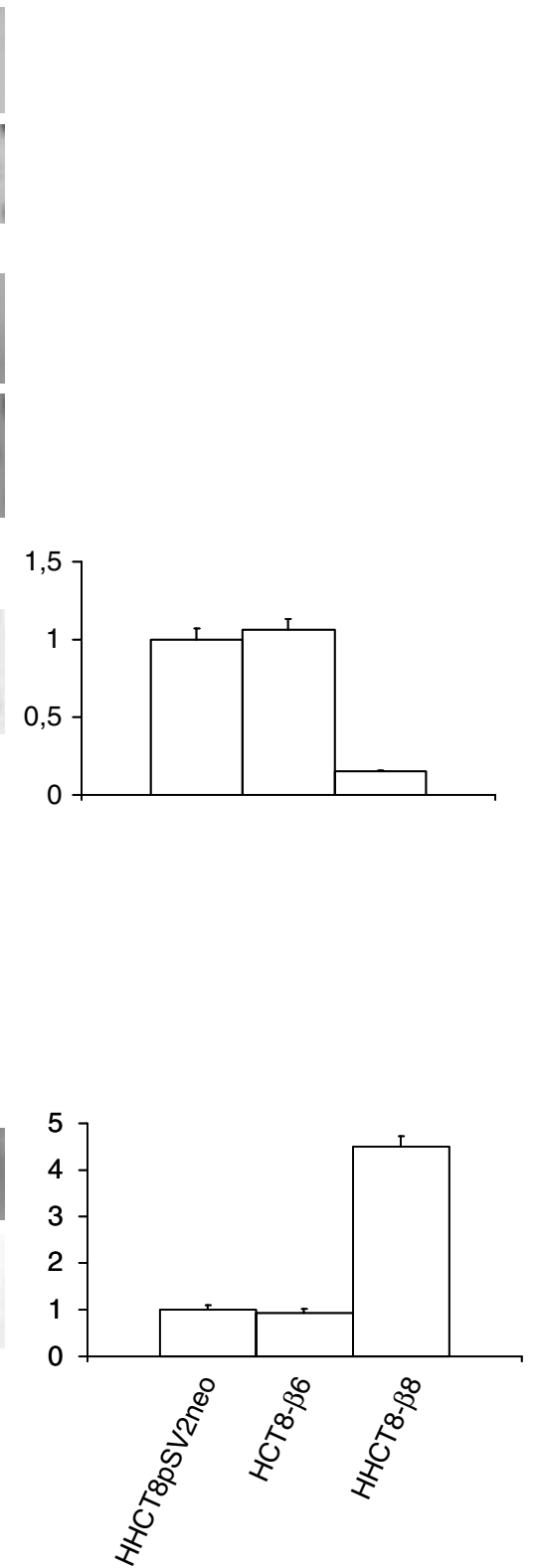

Figure 6 Western blot analysis of the effects of ER $\beta$ over-expression on cell cycle components expression: (A) cdk4, (B) cyclin D1, (C) cdk2, (D) cyclin E, (E) p27KIP1 and (F) p21CIP1 expression in HCT8pSV2neo (left lane), HCT8- $\beta 6$ (middle lane) and HCT8- $\beta 8$ (right lane) cell clones. Expression of $\beta$-actin in each sample is shown in the lower panel of A-F. When protein modulation is present the quantitative analysis of the expression of the corresponding protein, normalized against $\beta$-actin, is reported close to each Western-blotting panel. Results are expressed as percentage of control (HCT8pSV2neo cells) and are representative for one additional experiment. 
A

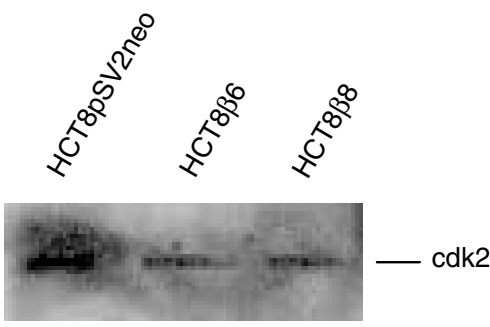

B

IP: cyclin E
kinase
$\mathrm{S}+\mathrm{G}_{2} / \mathrm{M}$

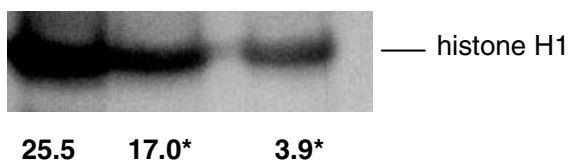

Figure 7 CycinE/cdk2 complex kinase activity on histone $\mathrm{H} 1$ substrate. Total cell lysates from control cells and from two clones expressing an intermediate (HCT8- $\beta 6$ ) or the maximal quantity (HCT8- $\beta 8$ ) of ER $\beta$ protein were immunoprecipitated (IP) with anti-cyclin $E$ antibody and immunoprecipitates were subjected to Western blot analysis (W) with anti-cdk2 antibody (A) or used for $\mathrm{H} 1$ kinase assay $(B)$. The proliferative fraction in the culture is reported as $S+G_{2} / M$. The results are expressed as the mean of three experiments \pm S.D. ${ }^{*} P<0.01$ vs HCT8pSV2neo cells.

intermediate ER $\beta$ expression level, between that of untransfected cells and of the HCT8- $\beta 8$ clone, showed intermediate proliferative and morphological features. Our observation is in agreement with what observed by Lazennec et al. (2001) in breast cancer cells (MDAMB-231), where ER $\beta$ inhibition of cell proliferation was ligand-independent, whereas ER $\beta$ was able to regulate reporter genes in a ligand-dependent manner. Moreover, these results reinforce the interpretation of a role for ER $\beta$ as a negative regulator of colon tumour growth based on reduced ER $\beta$ expression in normal compared with cancerous colonic mucosa that, conversely, showed a greater abundance of ER $\alpha$ mRNA (Enmark et al. 1997, Moore et al. 1998, Foley et al. 2000, Campbell-Thompson et al. 2001, Weyant et al. 2001). Altogether, these observations point to ER $\beta$ expression in colon cancer as a potential prognostic indicator of tumour progression but this requires confirmation in prospective clinical trials.

An important question to be answered is the mechanism through which over-expression of ER $\beta$ affects colon cancer cell proliferation by a ligandindependent pathway. Indeed, steroid receptors could be activated in the absence of their ligands, depending on the cell type and on promoters and activators (Weigel \& Zhang 1998, Tremblay \& Giguère 2001). In human colon cancer cells, ER $\beta$ is modulated by EGF and by IGF-I depending on endogenous ER $\beta$ expression with a cumulative effect of these growth factors exceeding that of 17ßE2. ER $\beta$ activation by these two growth factors was only partially abolished by treatment with ICI 164,384 . This result is in accordance with previous observations on the different effect of the antioestrogenic molecule on ER $\alpha$ and ER $\beta$ (Pace et al. 1997, Van Den Bemd et al. 1999).

The assumption that growth factors can modulate proliferation regulating ER $\beta$ activity was not supported by the results obtained on the effects of the two growth factors on cell proliferation in untransfected and HCT8- $\beta 8$ cells, where no statistical differences emerged. However, effects of exogenous doses of EGF and IGF-I used in proliferation assays could be masked by expression of endogenous growth factors. Indeed, both HCT8 cells and ER $\beta$-over-expressing derived clones produce both EGF and IGF-I and their cognate receptor mRNAs, becoming, therefore, prone to an autocrine loop of these growth factors (O'dwyer \& Benson 2002, Wang \& Sun 2002). Moreover EGF and IGF-I stimulate MAP kinase causing ERK1/2 phosphorylation and then altering directly the cell cycle. These results can explain both ligand-independent ER $\beta$ activation (Tremblay \& Giguère 2001) and perhaps the limited effect exerted by $17 \beta E 2$ on cell proliferation, because ER $\beta$ is constitutively activated through ligand-independent mechanisms. ER $\beta$ expression could, therefore, be interpreted as a regulator of the growth stimulatory or inhibitory actions of molecules (Platet et al. 2000), such as EGF (Lopez et al. 1995, Mendelsohn 1997, 2000) and IGF-I (Giovannucci 2001), on cancer-derived cell proliferation. In fact, possible proliferative effects by these growth factors on cancer cell lines could be reduced by 
highly expressed ER $\beta$ protein, while in cells expressing low levels of ER $\beta$ stimulatory actions of growth factor could become more dominant.

Another possible mechanism through which ER $\beta$ over-expression could inhibit colon cancer cell proliferation is by an increase in programmed cell death. The presence of the chromosome ladder phenomenon has already been described in the HCT8 cell line (Picariello et al. 1998). However, the absence of $180 \mathrm{bp}$ DNA fragmentation in untransfected cells and in three clones obtained from transfected cells did not support this hypothesis. This is in good agreement with the overall observations regarding the morphological features of ER $\beta$ over-expressing cells, exhibiting reduced cell growth without changes in cell death rate.

Finally, altered expression of cell cycle regulators and the subsequent deregulation of the cell cycle may be important steps in tumour promotion and are the most consistently found events in human malignancies including colorectal cancer (Hartwell \& Kastan 1994). Changes in cyclin D1, cyclin E, p21CIP1, and p27KIP1 expression have been described in various stages of colorectal cancer in animal and human tissues and in various cell lines (Sutter et al. 1997, Yamamoto et al. 1999, Hur et al. 2000). Moreover, c-Myc, cyclin D1, p21CIP1, and the cyclin E/cdk2 complex have been identified as central components of oestrogen regulation of cell cycle progression and hence as potential downstream targets that contribute to the role of oestrogen-induced carcinogenesis (reviewed in Foster et al. 2001, Doisneau-Sixou et al. 2003). However, most of the information regarding ERs and cell cycle regulation refers to $\mathrm{ER} \alpha$ and derives from studies on breast cancer cell lines and engineered cell models (reviewed in McDonnel \& Norris 2002). Moreover, several human tissues co-express both ERs and this is a confounding factor in interpreting the effects of their agonist and antagonist ligands. In HCT8 cells, ER $\beta$ over-expression induced an increase in cdk4 protein of up to fourfold. This finding is in apparent contradiction with data on cell proliferation as active cdk4complex is a central key regulator of DNA synthesis initiation (Weinberg 1995). However, in HCT8 cells this does not seem to represent a mitogenic stimulus per se, since it is not associated with a contemporary increase in cyclin D1, the essential modulator for entry into the proliferative stage of the cell cycle (Prall et al. 1998). Indeed, in another cell system a similar effect was observed on cyclin D1 but not on cdk-4 contemporary to the inhibition of cell growth (Ström et al. 2004). More importantly, ER $\beta$ induced a 4-fold reduction and a 4.5-fold induction in cyclin $\mathrm{E}$ and p21CIP1 expression respectively. Cyclin $E$ is a critical component of the active cdk 2 complex which drives the passage from $\mathrm{G} 1$ into $\mathrm{S}$ phase, and over-expression is usually present in a significant fraction of human colon carcinomas (Sutter et al. 1997). In the T47D breast cancer cell line, over-expression of ER $\beta$ induced a decrease of both cyclins $\mathrm{E}$ and $\mathrm{A}$ in a ligand-dependent manner (Ström et al. 2004). This is clearly different from what was observed in HCT8 cells where ER $\beta$ action on cyclin $\mathrm{E}$ regulation is ligand independent. Moreover, the use of a model that lacks ER $\alpha$ expression makes it possible to state that cyclin $\mathrm{E}$ regulation is due to a direct action of ER $\beta$ repressing the activity of the cyclin E promoter. Furthermore, induction of p21CIP1 expression represents an additional mechanism through which ER $\beta$ controls the colon cancer cell cycle, as the protein is essential in mammary cancer cells for growth and cell cycle arrest (Carroll et al. 2002, Licznar et al. 2003). Indeed, alteration in the expression of these proteins is sufficient to induce a G1-S cell cycle arrest in this cell model. These data clearly demonstrate the existence of an ER $\beta$-induced regulation of cell cycle components, supporting its anti-proliferative effect, and this action seems to be dose dependent. In fact, a doubled quantity of ER $\beta$ protein is sufficient to induce cdk 4 expression whereas for cyclin E and p21CIP1 induction and, most importantly, to provide a clear effect on the cell cycle, a quadruple quantity is needed. A similar anti-proliferative effect was observed in breast cancer MCF-7 cells infected with adenovirus-ER $\beta$. In this cell model ER $\beta$ inhibited cell proliferation and tumour formation by causing $\mathrm{G} 2$ cell cycle arrest mainly due to inhibition of cyclin A and induction of p21CIP1, p27KIP1 and c-myc mRNAs expression. These effects were almost linked due to a ligand-independent action of ER $\beta$ as $17 \beta E 2$ produced only a modest G2 arrest enhancement (Paruthiyil et al. 2004).

In conclusion, ER $\beta$ plays an anti-proliferative role in colon cancer cells in a ligand-independent fashion, directly regulating some cell cycle components, namely cyclin E and p21CIP1 and then causing a G1 cell cycle arrest. Altogether, these observations point to ER $\beta$ expression in colon cancer as a potential prognostic indicator of tumour progression and a potential target for chemotherapy with ER $\beta$-selective oestrogenic molecules.

\section{Acknowledgements}

This study was supported by grants from COFIN MURST 2001 to F T, from the Italian National Health System Project 'Human exposure to xenobiotics with potential endocrine activities: evaluation of the risks 
for reproduction and development' (2000), from AIRC 2000 to M L B and from the Fondazione Ente Cassa di Risparmio di Firenze, Florence, Italy. The authors declare that there is no conflict of interest that would prejudice the impartiality of this scientific work.

\section{References}

Arai N, Ström A, Rafter JJ \& Gustafsson JA 2000 Estrogen receptor beta mRNA in colon cancer cells: growth effect of estrogen and genistein. Biochemical and Biophysical Research Communications 270 425-433.

Calle EE, Miracle-McMahill HL, Thun MJ \& Heath CW Jr, 1995 Estrogen replacement therapy and risk of fatal colon cancer in a prospective cohort of postmenopausal women. Journal of the National Cancer Institute 87 517-523.

Campbell-Thompson M, Lynch IJ \& Bhardwaj B 2001 Expression of estrogen receptor (ER) subtypes and ER $\beta$ isoforms in colon cancer. Cancer Research 61 632-640.

Carroll JS, Swarbrick A, Musgrove EA \& Sutherland RL 2002 Mechanisms of growth arrest by c-myc antisense oligonucleotides in MCF-7 breast cancer cells: implications for the antiproliferative effects of antiestrogens. Cancer Research 62 3126-3131.

Chlebowski RT, Wactawski-Wende J, Ritenbaugh C, Hubbel FA, Ascensao J, Rodabough RJ, Rosenberg CA, Taylor VM, Harris R, Chen C, Adams-Campbell LL \& White E 2004 Estrogen plus progestin and colorectal cancer in postmenopausal women. New England Journal of Medicine 350 991-1004.

Cowley SM \& Parker MG 1999 A comparison of transcriptional activation by $\mathrm{ER} \alpha$ and ER $\beta$. Journal of Steroid Biochemistry and Molecular Biology 69 165-175.

deCosse JJ, Ngoi SS, Jacobson JS \& Cennerazzo WJ 1993 Gender and colorectal cancer. European Journal of Cancer Prevention 2 105-115.

Doisneau-Sixou SF, Sergio CM, Carroll JS, Hui R, Musgrove EA \& Sutherland RL 2003 Estrogen and antiestrogen regulation of cell cycle progression in breast cancer cells. Endocrine-Related Cancer 10 179-186.

Enmark E, Pelto-Huikko M, Grandine K, Lagerkrantz S, Lagerkrantz J, Fried G, Nordenskjold M \& Gustafsson JA 1997 Human estrogen receptor beta-gene structure, chromosomal localization, and expression pattern. Journal of Clinical Endocrinology and Metabolism 82 4258-4265.

Fiorelli G, Picariello L, Martineti V, Tonelli F \& Brandi ML 1999 Functional estrogen receptor $\beta$ in colon cancer cells. Biochemical and Biophysical Research Communications 261 521-527.

Foley EF, Jazaeri AA, Shupnik MA, Jazaeri O \& Rice LW 2000 Selective loss of estrogen receptor $\beta$ in malignant human colon. Cancer Research 60 245-248.

Foster JS, Henley DC, Ahamed S \& Wimalasena J 2001 Estrogens and cell-cycle regulation in breast cancer. Trends in Endocrinology and Metabolism 12 320-327.
Giovannucci E 2001 Insulin, insulin-like growth factors and colon cancer: a review of the evidence. Journal of Nutrition 131 3109S-3120S.

Grodstein F, Martinez ME, Platz EA, Giovannucci E, Colditz GA, Kautzky M, Fuchs C \& Stampfer MJ 1998 Postmenopausal hormone use risk for colorectal cancer adenoma. Annals of Internal Medicine 128 705-712.

Grodstein F, Newcomb PA \& Stampfer MJ 1999 Postmenopausal hormone replacement therapy and the risk of colorectal cancer: a review and meta-analysis. American Journal of Medicine 106 574-582.

Hartwell LH \& Kastan MB 1994 Cell cycle control and cancer. Science 266 1821-1828.

Hur K, Kim JR, Yoon BI, Lee JK, Choi JH, Oh GT \& Kim DY 2000 Overexpression of cyclin D1 and cyclin E in 1,2dimethylhydrazine dihydrochloride-induced rat colon carcinogenesis. Journal of Veterinary Science 1 121-126.

Kampman E, Potter JD, Slattery ML, Caan BJ \& Edwards S 1997 Hormone replacement therapy, reproductive history, and colon cancer: a multi-centre, case-control study in the United States. Cancer Causes and Control 8 146-158.

Lazennec G, Bresson D, Lucas A, Chauveau C \& Mignon F $2001 \mathrm{ER} \beta$ inhibits proliferation and invasion of breast cancer cells. Endocrinology 142 4120-4130.

Levi F, La Vecchia C, Randimbison LteVC \& Franceschi S 1991 Patterns of large bowel cancer by subside, age, sex and marital status. Tumori 77 246-251.

Licznar A, Caporali S, Lucas A, Weisz A, Vignon F \& Lazennec G 2003 Identification of genes involved in growth inhibition of breast cancer cells transduced with estrogen receptor. FEBS Letters 553 445-450.

Liu MM, Albanese C, Anderson CM, Hilty K, Webb P, Uht RM, Price RH, Pestell RG Jr \& Kushner PJ 2001 Opposing action of estrogen receptors $\alpha$ and $\beta$ on cyclin D1 gene expression. Journal of Biological Chemistry 277 24353-24360.

Lopez D, Oates PS \& House AK 1995 Effects of epidermal growth factor and mitogenic pathway inhibitors on rat colon cancer proliferation in vitro. Anticancer Research $\mathbf{1 5}$ 157-162.

McDonnel DP \& Norris JD 2002 Connections and regulation of the human estrogen receptor. Science $\mathbf{2 9 6}$ 1642-1644.

Mendelsohn J 1997 Epidermal growth factor receptor inhibition by a monoclonal antibody as anticancer therapy. Clinical Cancer Research 3 2703-2707.

Mendelsohn J 2000 Blockade of receptors for growth factors: an anti-cancer therapy. Clinical Cancer Research 6 747-753.

Moore JT, McKee DD, Slentz-Kesler K, Moore LB, Jones SA, Horne EL, Su JL, Kliewer SA, Lehmann JM \& Willson TM 1998 Cloning and characterization of human estrogen receptor beta isoforms. Biochemical and Biophysical Research Communications 247 75-78.

Nakayama Y, Sakamoto H, Satoh K \& Yamamoto T 2000 Tamoxifen and gonadal steroids inhibit colon cancer 
growth in association with inhibition of thymidylate synthase, survivin and telomerase expression through estrogen receptor beta mediated system. Cancer Letters $16163-71$.

Nanda K, Bastian LA, Hasselblad V \& Simel DL 1999 Hormone replacement therapy and the risk of colorectal cancer: a meta-analysis. Obstetrics and Gynecology $\mathbf{9 3}$ 880-888.

Niwa H, Yamamura K \& Miyazaki J 1991 Efficient selection for high-expression transfectants with a novel eukaryotic vector. Gene 108 193-199.

O'dwyer PJ \& Benson AB 3rd 2002 Epidermal growth factor receptor-targeted therapy in colorectal cancer. Seminars in Oncology 29 (5 Suppl 14) 10-17.

Pace P, Taylor J, Suntharalingman S, Coombes RC \& Ali S 1997 Human estrogen receptor beta binds DNA in a manner similar to and dimerizes with estrogen receptor alpha. Journal of Biological Chemistry 272 25832-25838.

Paruthiyil S, Parmar H, Kerekatte V, Cunha GR, Firestone GL \& Leitman DC 2004 Estrogen receptor $\beta$ inhibits human breast cancer cell proliferation and tumor formation by causing a G2 cell cycle arrest. Cancer Research 64 423-428.

Pasi AJ \& Robert JM 2000 Chemoprevention of colorectal cancer. New England Journal of Medicine 342 1960-1968.

Picariello L, Fiorelli G, Benvenuti S, Brandi ML, Galli G, Malentacchi C, Montali E, Bigozzi U, Ficari F \& Tonelli F 1997 In vitro bioeffects of the antiestrogen LY117018 on desmoid tumors and colon cancer cells. Anticancer Research 17 2099-2104.

Picariello L, Brandi ML, Formigli L, Zecchi Orlandini S, Dolara P, Caderni G, Raimondi L \& Tonelli F 1998 Apoptosis induced by sulindac sulphide in epithelial and mesenchymal cells from human abdominal neoplasms. European Journal of Pharmacology 360 105-112.

Platet N, Cunat S, Chalbos D, Rochefort H \& Garcia M 2000 Unliganded and liganded estrogen receptors protect against cancer invasion via different mechanisms. Molecular Endocrinology 14 998-1009.

Prall OW, Rogan EM \& Sutherland RL 1998 Estrogen regulation of cell progression in breast cancer cells. Journal of Steroid Biochemistry and Molecular Biology $\mathbf{6 5}$ 169-174.

Ries LA, Winyn PA, Miller DS, Howe HL, Weir HK, Rosenberg HM, Vernon SW, Crohn K \& Edwards BK
2000 The annual report to the nation on the status of cancer 1973-1979. Cancer 88 2398-2424.

Ström A, Hartman J, Foster JS, Kietz S, Wimalasena J \& Gustafsson JA 2004 Estrogen receptor $\beta$ inhibits $17 \beta$-estradiol-stimulated proliferation of the breast cancer cell line T47D. PNAS 101 1566-1571.

Sutter T, Doi S, Carnevale KA, Arber N \& Weinstein IB 1997 Expression of cyclins D1 and E in human colon adenocarcinomas. Journal of Medicine 28 285-309.

Tompkins WA, Watrach AM, Schmale JD, Schultz RM \& Harris JA 1974 Cultural and antigenic properties of newly established cell strains derived from adenocarcinomas of the human colon and rectum. Journal of the National Cancer Institute 52 1101-1110.

Tremblay A \& Giguère V 2001 Contribution of steroid receptor coactivator-1 and CREB binding protein in ligand-independent activity of estrogen receptor $\beta$.

Journal of Steroid Biochemistry and Molecular Biology 77 19-27.

Van Den Bemd GCM, Kuiper GGJM, Pols HAP \& Van Leeuwen JPTM 1999 Distinct effects on the conformation of estrogen receptor $\alpha$ and $\beta$ by both the antiestrogens ICI 164,384 and ICI 182,780 leading to opposite effects on receptor stability. Biochemical and Biophysical Research Communications 261 1-5.

Wang Y \& Sun Y 2002 Insulin-like growth factor receptor-1 as an anti-cancer target: blocking transformation and inducing apoptosis. Current Cancer Drug Targets 2 191-207.

Weigel NL \& Zhang Y 1998 Ligand-independent activation of steroid hormone receptors. Journal of Molecular Medicine 76 469-479.

Weinberg RA 1995 The retinoblastoma protein and cell cycle control. Cell 81 323-330.

Weyant MJ, Carothers AM, Mahmoud NN, Bradlow HL, Remotti H, Bilinski RT \& Bertagnolli MM 2001 Reciprocal expression of $\mathrm{ER} \alpha$ and $\mathrm{ER} \beta$ is associated with estrogen-mediated modulation of intestinal tumorigenesis. Cancer Research 61 2547-2551.

Yamamoto H, Soh JW, Shirin H, Xing WQ, Lim JT, Yao Y, Slosperg E, Tomita N, Scieren I \& Weinstein IB 1999 Comparative effects of overexpression of p27Kip1 and p21Cip1/Waf1 on growth and differentiation in human colon carcinoma cells. Oncogene 18 103-115. 
